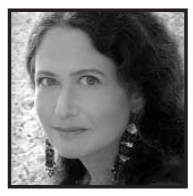

\title{
Commentary:
}

\section{Three Keys: Opening the Gate of Poetry to Young Writers}

Jane Hirshfield

\section{ABSTRACT}

The author draws on her experience as a poet and a teacher to offer three key elements for teaching students poetry. She believes that the teacher's own passion about poetry is the first key to letting the imagination rise. The second key is freedom of mind, both for the teacher and the students, which allows students to explore in many directions, without the constraints of pre-set rules, conventions and grades. The "writing invitation" is the third key. In this part, she outlines several innovative ways to invite students to write poetry, giving them guidelines to start from while allowing their creativity to flourish.

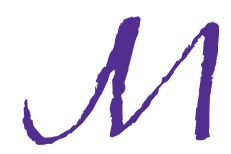

y first job as a poet was working in California Poets in the Schools. In that superb and still thriving program, entering poets apprentice with other poets already teaching, then, once they have been authorized, offer workshops to schools in their local community. The system of local, rather than visiting, writers allows long-term relationships and long-term instructionmany schools have poets return year after year, to work with every class for five or ten sessions. I saw generations of young people fall in love with words, their expressive powers, and exhilaration of imaginative thinking. This way of teaching offers a broad entrance to creative writing and the appreciation of poetry. It also opens a gate into a genuine and lasting literacy: students feel written language as their own to use freely and joyfully, they find it a part of their lives as intimate, empowering, and useful as their own hands or feet. Years after I stopped teaching in the local schools, three 
now-adolescent boys came up while I waited in line outside a movie and begged me to listen to their poems.

The first key to teaching poetry writing is the teacher's own passion. As a practicing poet, I came into the classroom filled with joy in the art and its possibilities. Many classroom teachers feel this as well, of course-it doesn't matter if a person is a "published poet"; what matters is that they have known for themselves the exhilaration of words. The yeast of passion is what lets imagination rise.

The second key is freedom of mind-for students, and for the teacher. During the classroom hour of poetry, writing wants to be an open field. Spelling does not matter, punctuation rules do not matter, rules of grammar do not matter. It's far better if poems are not graded. The sigh of relief is palpable, but something more important happens as well: students can remember for themselves that the point of language, written or spoken, is, quite simply, to express, to understand, and to be understood. It is true, the rules do need to be learned, but writing time free of concern for pre-set rules allows students to discover that the conventions of comprehensibility exist to serve them, not vice versa. As for freedom of subject, for whatever reason, I never had any serious problem with "transgressive" writing. The teacher's unshockability takes away the incentive to shock perhaps. If a student is pushing the limits, the teacher can just encourage something more imaginative, more original, more daring in a different direction; and mostly, the original invitation to write can be set up in such a way that the problems just don't occur. A last part of this freedom of mind is that you cannot ever know which student will astonish. Time after time, I've seen the students who were not the "good writers" be the ones to write poems that amazed themselves, their classmates, their homeroom teachers. Good poems slip through the cracks where they are most needed. Such a moment of self-surprise can be lifechanging. The route to this kind of surprise is praise-whatever is on the page, there will be some strength to encourage further. The first draft of a poem is a failure-free zone.

The third key is crafting the writing invitation itself. A good writing suggestion will be simple to grasp, but profound in its possibilities of fulfillment. I found that I always needed to structure my own lessons and choose my own model poems; this was part of coming into the classroom with passion. Still, what follow are a sample few of my own ideas for some poetry "starts."I tried, in each, to have some underlying skill I was also introducing, sometimes by name, sometimes-especially in the younger grades—without calling it "simile," "extended metaphor," or "ode."With older 
students, these concepts can be taught more explicitly, though lightly: the poem itself is always the point. Awareness of the skill or underlying concept was useful for me as a teacher, as well; it gave my classroom ideas a kind of backbone and rigor. I was not asking students to write arbitrarily, and I was honing my own understanding of the way that good poems actually work. It also made me aware of the variety of approaches I could take, so that each writing session was quite distinct from the last. I wanted to convey the limitlessness of poems, and to set out enough variety of possibilities that every student would find at least one way of writing that thrilled.

There are two basic styles of writing invitation-one begins with an idea. The basic strategy here is often to read aloud a few model poems that work in some connected way, then ask the class to do something along the same lines. The through-line could be a subject matter (a poem that starts with a fact from science, a poem about losing someone or something loved). The through-line might equally be a rhetorical or grammatical strategy. One example: the poem as recipe for doing something - a poem titled "How to Dance," for instance, would almost necessarily be written as a set of instructions, and most students would intuitively use the imperative voice. For this kind of invitation, I might first have students make a list of five or ten activities, then read them some published poems couched as instruction or recipe; then I would ask them to pick an activity from their list and perhaps write a poem in the form. A variation might be to suggest the poem be titled "How to Begin to "The"begin to" opens and broadens the imagination in a certain direction. But mostly this invitation would be simply "How To Dance," or "How to Eat Breakfast at 3 P.M." or "How to Sing to an Owl." It's helpful to have a broad set of model poems, with a broad range between them, or else a set of your own example titles, as here, to suggest.

The other basic mode of invitation is to offer a template or structure of some kind. This is what you are doing if you ask students to write a haiku, or sonnet, but it is not only a matter of musical and metrical form. For very young writers, for instance, those just learning to write, I might write on the blackboard or hand out copies of this "grid":

The taste of is looks like

The sound of is

When I touch it feels like

The scent of makes me think of 
Before asking the students to write, I might ask the class to suggest names of emotions of all kinds: joy, anger, loneliness, restlessness. At this stage you can encourage freedom as well-“What are some less usual emotions? Some strange ones?" There is the chance also to invite in the "negative" as well as the positive"fear," "shame." All get written on the board. All are welcomed as part of what it means to be human. The students are then told to pick one emotion, either the one they suggested or any of the others, and to write about it, using the pattern above, with all five senses. I encourage them to make the second blank a noun (a thing) rather than an adjective, since the hope is that the result will be a series of similes rather than judgments. All the electrical energy is in the unexpected connection, present in "The taste of an apple is a large house in summer with its windows wide open," not present in "The taste of an apple is sweet." It may help, especially in the youngest grades, to do one or two of the poems verbally first, as a group, before asking the students to write or dictate their own. Under the surface of this seemingly simple invitation are two different intentions. One: the imagination cannot help but be engaged. Synaesthesia is unavoidable, freedom of mind inevitable. Yet every first grader can do this, especially once he/she understands there are no wrong answers. "The taste of anger is a charging elephant." "The sound of loneliness is an icicle hanging from a roof in the dark." The second undercurrent intention is that the child who may have something he/she needs to explore for personal reasons has the chance to do that. A frightened child might choose to write about fear, or might choose to experiment with "courage." In either case, there is a safe vessel for taking that emotion and looking at in new ways, gaining some mastery over its life in the mind and heart, gaining the sense of some breathing room around it. This is part of the real work of poetry, whether for a seven year old or a seventy year old.

The same exercise could be used in an eighth grade classroom, but as preliminary. The first task (creating five similes, one for each sense) isn't the poem, it's just taking some things out of the cupboard to have on the counter. Once the template of an emotion approached through the imagination and senses is there, students can then be asked to choose the one they like best and turn that into a full-length poem. The exercise becomes one of extended metaphor or narrative, and the student is continuing to deepen his/her relationship with the underlying reason this emotion, this image, was chosen to explore.

Very often, in my poetry teaching, I begin with a step in which the writer chooses something for him or herself. This seems to me important-no one should be asked to write about what they don't care about, and subject matters and attitudes cannot be imposed. Making a list or choosing a subject also means that the 
students have already "signed on" before they are asked to do anything. The psyche is already in motion before it is then given the deeper request.

Another teaching idea: the ode, a poem of praise. For this, you could ask the students, before they know the task, to simply write down a list of ordinary things, "nothing special." Then bring in a series of Pablo Neruda's odes to common and unexpected objects. Neruda's "Ode to a Watch Ticking in the Night" or "Ode to a Dead Fish in the Market" or "Ode to the Onion" throw open doors and set the spirit toward both the wild and the generous tunings. Odes might also be written to something the student may be ambivalent about-the initial list to draw a subject from could be "emotions l'd rather not feel." (It's best here to make clear the poems cannot be about people, and the invitation generally works better if the ode is not devoted to something that the student feels forced to praise because it is already condoned as "good.")

One writing invitation (I think of it, for reasons that will soon be obvious, as "The Concrete of Abstraction") invariably startles students with the power of language itself to both surprise and cohere. Have the students write two columns of words next to one another. First, on the left side of the page, ask them to list ten concrete nouns (objects, things you could see or hear or taste). Once that is done, ask them to make a list just to the right of that one, with ten abstract nouns (the concept, if unfamiliar, is a bit harder to explain-l'd usually suggest "any subject you study in school, ideas, the names of emotions," and then get some examples onto the board for students to draw from). Once both lists are complete, ask students to write between each pair of words in the two columns, the word "of." After a moment or two, the laughter begins, students start showing them to one another. Hear some- "the jazz piano of history, "'the icicle of sorrow," "the high heels of judgment" - then have them pick a favorite, and write a poem with the chosen image-phrase as either the title or the first few words.

One example of what might come out of this invitation, from a fourth grader:

The White Horse of Winter

The white horse of winter

With a mane of snow

And eyes of ice. 
The green horse of spring,

Green for the grass and green

Of the trees.

The many colored horse of

Fall,

With eyes of red leaves

And a mouth of fog and coldness.

And last but not least,

The horse of summer,

The horse of children playing.

This essay is a skimming of the surface - but there are many books available with other ideas for writing suggestions. The basic thing I hope I've conveyed is a spirit and an expectation of astonishment. A person is never mechanical, nor is a poem. The only reason to write is to know the world more fully and more newly, and to be known more fully and newly. The last thing I will suggest, then, is always to have some time for hearing what's been written. There is a line in a poem by the Polish poet Adam Zagajewski: "Poems from poems, songs from songs, paintings from paintings, always this friendly impregnation" $(1985$, p. 19). Good poems themselves create the hunger for more poetry. In the end, the teacher wants to disappear, a listener as entranced as any other by the words that have come into the room, dipped from some river of limitless perception, knowledge, and feeling that is always flowing into and from us, if we only can turn our ears towards its musical voice.

\section{References}

Zagajewski, A. (1985). A River. (tr: Renata Gorczynski) Tremor. NY: Farrar, Straus and Giroux, 1985. 


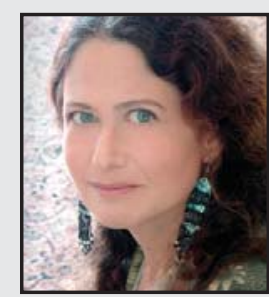

Jane Hirshfield is the author of six published books of poetry, including After (HarperCollins, 2006, US; Bloodaxe Books, 2006, UK), named a best book of the year by The Washington Post, The San Francisco Chronicle, and England's Financial Times and Given Sugar, Given Salt (HarperCollins, 2001). Her book of essays, Nine Gates: Entering the Mind of Poetry (HarperCollins, 1997), has become a classic in its field, read not only by those interested in poetry, but in classes in such diverse fields as architecture, choreography, and painting. She has taught at Bennington College, U.C. Berkeley, and elsewhere, and for five years was a poet-teacher in the California Poets in the Schools program.

LINK TO:

www.barclayagency.com/hirshfield.html 